\title{
PENGARUH MANAJEMEN LABA TERHADAP TINGKAT PENGUNGKAPAN LAPORAN KEUANGAN PADA PT CHAROEN POKPHAND INDONESIA TBK
}

\author{
Agung Rachmadi \\ Dosen Pasca Sarjana Manajemen Universitas Saburai \\ Jl. Imam Bonjol No. 486, Langkapura, Bandar Lampung, 35118 \\ email: agungrachmadi1811@gmail.com \\ Hairudin \\ Dosen Program Studi Kewirausahaan Universitas Mitra Indonesia \\ Jalan Zainal Abidin Pagar Alam No. 07, Gedongmeneng, Rajabasa, Bandar \\ Lampung, Indonesia 35144 \\ email: khairuddinkusman1@gmail.com \\ Hasbullah \\ Dosen Program Studi Manajemen Universitas Mitra Indonesia \\ Jalan Zainal Abidin Pagar Alam No. 07, Gedongmeneng, Rajabasa, Bandar \\ Lampung, Indonesia 35144 \\ email: hasbullah@umitra.ac.id
}

\begin{abstract}
The influence of earning management at the of level disclosure financial statement PT Charoen Pokphand Indonesia Tbk. The purpose of this research is to find out the correlation which occours between earning management used is measured by using variable profit, leverage,company size, liquidity and level disclosure financial statement, at company PT Charoen Pokphand Indonesia Tbk. The sample used is financial statement PT Charoen Pokphand Indonesia Tbk year 2011-2016. Data analysis tecniques in this study using analysis regression linear multiple. Based on the test simultaneous results of the research showed variable independent profit, leverage, company size, liquidity on the together influential signifi cantly to level disclosure financial statement PT Charoen Pokphand Indonesia Tbk. and results partial test showed profit influential signifi to level disclosure financial statement, results partial test showed leverage influential signifi to level disclosure financial statement, results partial test showed company size influential signifi to level disclosure financial statement, and results partial test showed liquidity no influential significant to level disclosure financial statement PT Charoen Pokphand Indonesia Tbk.

Keywords: Profit, Leverage, Company Size, Liquidity and Level Disclosure Financial Statement.
\end{abstract}

\begin{abstract}
ABSTRAK
Pengaruh manajemen laba pada tingkat pengungkapan laporan keuangan PT Charoen Pokphand Indonesia Tbk. Tujuan dari penelitian ini adalah untuk mengetahui hubungan yang terjadi antara manajemen laba yang digunakan diukur dengan menggunakan variabel laba, leverage, ukuran perusahaan, likuiditas dan tingkat pengungkapan laporan keuangan pada perusahaan PT Charoen Pokphand Indonesia Tbk. Sampel yang digunakan adalah laporan keuangan PT Charoen Pokphand Indonesia Tbk tahun 2011-2016. Teknik analisis data dalam penelitian ini menggunakan analisis regresi linier berganda. Berdasarkan uji simultan hasil penelitian menunjukkan variabel independent profit, leverage, ukuran perusahaan, likuiditas secara bersama-sama berpengaruh signifikan terhadap tingkat pengungkapan laporan keuangan PT Charoen Pokphand Indonesia Tbk. Dan hasil uji parsial menunjukkan laba berpengaruh signifikan terhadap tingkat pengungkapan laporan keuangan, hasil uji parsial menunjukkan leverage berpengaruh signifikan terhadap tingkat pengungkapan laporan keuangan, hasil uji parsial menunjukkan ukuran perusahaan berpengaruh signifikan terhadap tingkat pengungkapan laporan keuangan, dan hasil uji parsial
\end{abstract}


menunjukkan likuiditas tidak berpengaruh signifikan. untuk tingkat pengungkapan laporan keuangan PT Charoen Pokphand Indonesia Tbk.

Kata Kunci: Manajemen Laba, Tingkat Pengungkapan Laporan.

\section{PENDAHULUAN}

Menurut Julia Halim et al (2005) Jika pada suatu kondisi dimana pihak manajemen tidak berhasil mencapai target laba yang ditentukan, maka manajemen akan memanfaatkan fleksibilitas yang diperbolehkan oleh standar akuntansi dalam menyusun laporan keuangan untuk memodifikasi laba yang dilaporkan. Tindakan ini disebut dengan earning management. manajemen laba atau earning management merupakan pilihan metode akuntansi yang secara sengaja dipilih oleh manajemen untuk tujuan tertentu. Manajemen termotivasi untuk memperlihatkan kinerja yang baik dalam menghasilkan nilai atau keuntungan maksimal bagi perusahaan sehingga manajemen cenderung memilih dan menerapkan metode akuntansi yang dapat memberikan informasi laba yang lebih baik. Para manager biasanya juga diberikan suatu target berguna untuk meningkatkan nilai perusahaan dan menarik banyak investor.

Perusahaan yang melakukan manajemen laba akan mengungkapkan lebih sedikit informasi dalam laporan keuangan agar tindakannya tidak mudah terdeteksi. Namun terdapat kemungkinan sebaliknya, jika manajemen laba dilakukan untuk tujuan mengkomunikasikan informasi dan meningkatkan nilai perusahaan, maka seharusnya hubungan yang terjadi adalah positif. Untuk menganalisis hubungan yang terjadi antara manajemen laba dan tingkat pengungkapan laporan keuangan, peneliti menggunakan variabel-variabel lain yang berpengaruh terhadap manajemen laba yaitu laba, ukuran perusahaan, leverage, serta variabel yang berpengaruh terhadap tingkat pengungkapan yaitu likuiditas. (Kasmir 2012)

Tujuan Penelitian ini adalah Untuk mengetahui pengaruh laba, leverage, ukuran perusahaan, terhadap tingkat pengungkapan laporan keuangan pada PT Charoen Pokphand Indonesia Tbk.

\section{TINJAUAN PUSTAKA}

Manajemen laba adalah pemilihan kebijakan akuntansi tertentu oleh manajer untuk mencapai tujuan tertentu, manajemen laba merupakan suatu proses pengambil langkah tertentu yang disengaja dalam batas prinsip akuntansi berterima umum untuk menghasilkan tingkat yang diinginkan dari laba yang dilaporkan. Definisi tersebut menunjukan manajemen laba sebagai aktivitas yang biasa dilakukan manajer dalam menyusun laporan keuangan. (Mieke Yuliana, 2015). Faktor Yang Mempengaruhi Manajemen Laba dapat dijabarkan sebagai berikut :

1. Laba

Laba merupakan perusahaan yang mempunyai rencana pemberian bonus akan lebih memilih metode akuntansi yang dapat menggeser laba dari masa depan ke masa kini sehingga perusahaan dapat menaikkan laba saat ini. Perusahaan yang mempunyai rencana pemberian bonus akan lebih memilih metode akuntansi yang dapat menggeser laba dari masa depan ke masa kini sehingga dapat menaikkan laba saat ini. Hal ini dikarenakan manajer lebih menyukai pemberian upah yang lebih tinggi untuk masa kini.

\section{Rasio Laverage}

Rasio leverage yaitu rasio untuk mengukur seberapa jauh aktiva perusahaan dibiayai dari hutang. Dengan mengetahui rasio leverage akan dapat menilai tentang posisi perusahaan terhadap seluruh kewajibannya kepada pihak lain, dapat mengetahui kemampuan perusahaan dalam memenuhi kewajibannya yang bersifat tetap, dan dapat mengetahui antara nilai aktiva tetap dengan modal. (Kasmir, 2012).

3. Ukuran Perusahaan

Ukuran perusahaan merupakan salah satu faktor yang dapat mempengaruhi manajemen dalam praktik perataan laba, karena perusahaan yang besar lebih cenderung lebih di perhatikan oleh masyarakat sehingga mereka akan lebih berhati hati dalam melakukan pelaporan keuangan. (Pujiningsih 2011) menuturkan 
bahwa, semakin besar ukuran perusahaan, biasanya informasi yang tersedia untuk investor dalam pengambilan keputusan sehubungan dengan investasi dalam saham tersebut semakin banyak.

4. Rasio Likuiditas

Rasio likuiditas merupakan rasio yang menggambarkan kemampuan perusahaan perusahaan dalam memenuhi kewajiban jangka pendek. Rasio likuiditas berfungsi untuk mengukur kemampuan perusahaan dalam memenuhi kewajibannya pada saat jatuh tempo. Baik kewajiban kepada pihak luar maupun dari dalam perusahaan. Rasio likuiditas menunjukan kemampuan perusahaan untung membayar hutang hutang (kewajiban) jangka pendek pada saat jatuhg tempo. Rasio likuiditas mengetahui kemampuan perusahaan dalam membiayai kewajiban hutang pada saat di tagih. (Kasmir 2012).

5. Tingkat Pengungkapan

Tingkat Pengungkapan (disclosure) adalah tingkat pengungkapan atas informasi yang diberikan sebagai lampiran pada laporan keuangan dalam bentuk catatan kaki atau tambahan. Informasi ini menyediakan penjelasan yang lebih lengkap mengenai posisi keuangan dan hasil operasi perusahaan. Tingkat pengungkapan laporan keuangan merupakan suatu cara untuk menyampaikan informasi yang terdapat dalam laporan keuangan suatu perusahaan. Pengungkapan merupakan semua materi yang harus diungkapkan termasuk informasi kuantitatif dan kualitatif yang sangat membantu pengguna laporan keuangan. (Tanor 2009).

Tingkat pengungkapan merupakan sarana penyampaian informasi secara lengkap kepada pihak-pihak yang terkait dalam proses pengambilan keputusan. Tingkat pengungkapan juga dilakukan sebagai upaya untuk mempertanggungjawabkan aktivitas perusahaan selama periode tertentu dalam menggunakan sumber yang ada di perusahaan.

6. Tujuan Tingkat Pengungkapan

Menurut Suwardjono (2008) secara umum, tujuan tingkat pengungkapan adalah menyajikan informasi yang dipandang perlu untuk mencapai tujuan pelaporan keuangan dan untuk melayani berbagai pihak yang mempunyai kepentingan berbeda-beda.

\section{METODELOGI PENELITIAN}

Desain penelitian adalah semua proses yang diperlukan dalam perencanaan dan pelaksaan penelitan. Penelitian yang dilakukan diskriptif yaitu untuk menjelaskan karaktristik variabel yang diteliti dalam suatu situasi. Tujuan penelitian diskriptif adalah memberikan kepada peneliti sebuah riwayat atau untuk menggambarkan aspekaspek yang relevan dengan penelitian deskriptif seseorang, organisasi, oreintasi industri, atau lainnya yang kemudian penelitian ini membantu peneliti untuk memberikan gagasan untuk penelitian lebih lanjut atau membuat keputusan tertentu yang sederhana.

Data yang digunakan dalam penelitian ini adalah data sekunder yang bersumber dari pihak eksternal. Pengumpulan data dilakukan dengan dokumentasi, studi pustaka dan observasi.

Jenis penelitian kuantitatif seperti berdasarkan fakta, bebas prasangka, menggunakan prinsip analisa, menggunakan hipotesa, menggunakan ukuran objektif (Arikunto, 2013).

Penelitian ini mengambil lokasi di PT Charoen Pokphand Indonesia Tbk di Jl. Ir. Sutami km 15, Desa Rejomulyo, Kecamatan Tanjung Bintang, Lampung Selatan, Lampung. Pada bulan Maret - Agustus 2017. Populasi dan sampel dalam penelitian ini adalah laporan keuangan PT Charoen Pokphand Indonesia Tbk. Laporan keuangan dari tahun 2011-2016, penelitian ini yang dijadikan sampel adalah laporan keuangan sebanyak 24 triwulan. Variabel independen dalam penelitian ini adalah laba, rasio leverage, ukuran perusahaan dan rasio likuiditas sedangkan variabel dependennya adalah tingkat pengungkapan laporan keuangan.

Definisi operasional dalam penelitian ini dijelaskan dalam tabel 3.1.

\section{HASIL DAN PEMBAHASAN}

\section{Uji Asumsi Klasik}

Uji Normalitas 
Jurnal Manajemen dan Bisnis Vol. 11 No. 1 Oktober 2020: 7 - 18

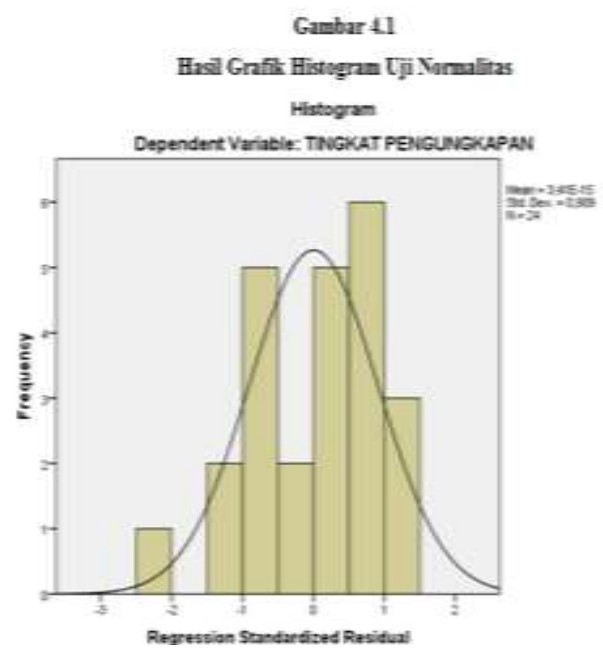

Berdasarkan gambar 4.1 grafik histogram menggambarkan data yang berdistribusi normal karena membentuk seperti lonceng (bell shaped). Grafik histogram uji normalitas yaitu dengan melihat grafik histogram dari penyebaran (frekuensi) data. Bentuk histogram seperti bentuk lonceng (bell shaped curve) mengindikasikan bahwa data berdistribusi normal.

Tabel 3.1

Definisi Operasional Variabel

\begin{tabular}{|c|c|c|c|c|}
\hline Variabel & Konsep & Indikator & Hasil & Skala \\
\hline $\begin{array}{c}\text { Laba } \\
\mathrm{X}_{1}\end{array}$ & $\begin{array}{l}\text { Laba merupakan } \\
\text { perusahaan yang } \\
\text { mempunyai rencana } \\
\text { pemberian bonus alsan } \\
\text { lebih memilih metode } \\
\text { akuntansi yang dapat } \\
\text { menggeser laba dari masa } \\
\text { depan ke masa kini } \\
\text { sehingga perusahaan dapat } \\
\text { menaikkan laba saat ini. }\end{array}$ & CRP $=\begin{array}{l}\text { Laba bersih tahun berjalan } \\
\text { Total altiva awal tahun } \\
\text { berjalan }\end{array}$ & $\%$ & Rasio \\
\hline $\begin{array}{c}\text { Leverage } \\
\mathrm{X}_{2}\end{array}$ & $\begin{array}{l}\text { Leverage ratio merupakan } \\
\text { rasio yang digunakan } \\
\text { untuk mengukur ajauh } \\
\text { mana aktiva perusahaen di } \\
\text { biayai hutang }\end{array}$ & Leverage $=\frac{\text { Total Debt }}{\text { Total Ekuitas }}$ & $\%$ & Rasio \\
\hline $\begin{array}{l}\text { Ukuran } \\
\text { perusahaen } \\
\text { (X3) }\end{array}$ & $\begin{array}{l}\text { Ukuran Perusahan } \\
\text { merupakan salah satu } \\
\text { faktor yang dapat } \\
\text { mempengaruhi manajemen } \\
\text { laba, karens perusahan } \\
\text { yang besar cenderung lebih } \\
\text { diperhatikan oleh } \\
\text { masyarakat aehingga } \\
\text { merelsa akan lebih berhati } \\
\text { hati dalam melakukan } \\
\text { laporan keuangan. }\end{array}$ & ROA $=\frac{\text { Laba Sebelum Pajak }}{\text { Total Asset }}$ & $\%$ & Rasio \\
\hline $\begin{array}{c}\text { Likuiditas } \\
\mathrm{X}_{4}\end{array}$ & $\begin{array}{l}\text { Likuiditas merupakan rasio } \\
\text { yang menggambarkan } \\
\text { kemampuan } \\
\text { perusahaen perusahaen } \\
\text { dalam memenuhi } \\
\text { kewajiban jangka pendek. }\end{array}$ & Current Ratio $=\frac{\text { Aktiva Lancar }}{\text { Hutang Lancar }}$ & $\%$ & Rasio \\
\hline $\begin{array}{c}\text { Tingksat } \\
\text { pengungkapan } \\
\text { laporan keuangan } \\
(\mathrm{Y})\end{array}$ & $\begin{array}{l}\text { Mengukur berapa banyal: } \\
\text { item laporan keuangan } \\
\text { yang diungksakpan oleh } \\
\text { perusahaen. }\end{array}$ & $\begin{array}{l}\text { Indeks Wallace } \\
\qquad \frac{\mathrm{n}}{\mathrm{k}} \times 100 \%\end{array}$ & $\%$ & Rasio \\
\hline
\end{tabular}

Sumber: Analisa Laporan Keuangan Kasmir (2012), data diolah (2017) 


\section{Gambar 4.2}

Hasil Grafik Normal Probability Plot

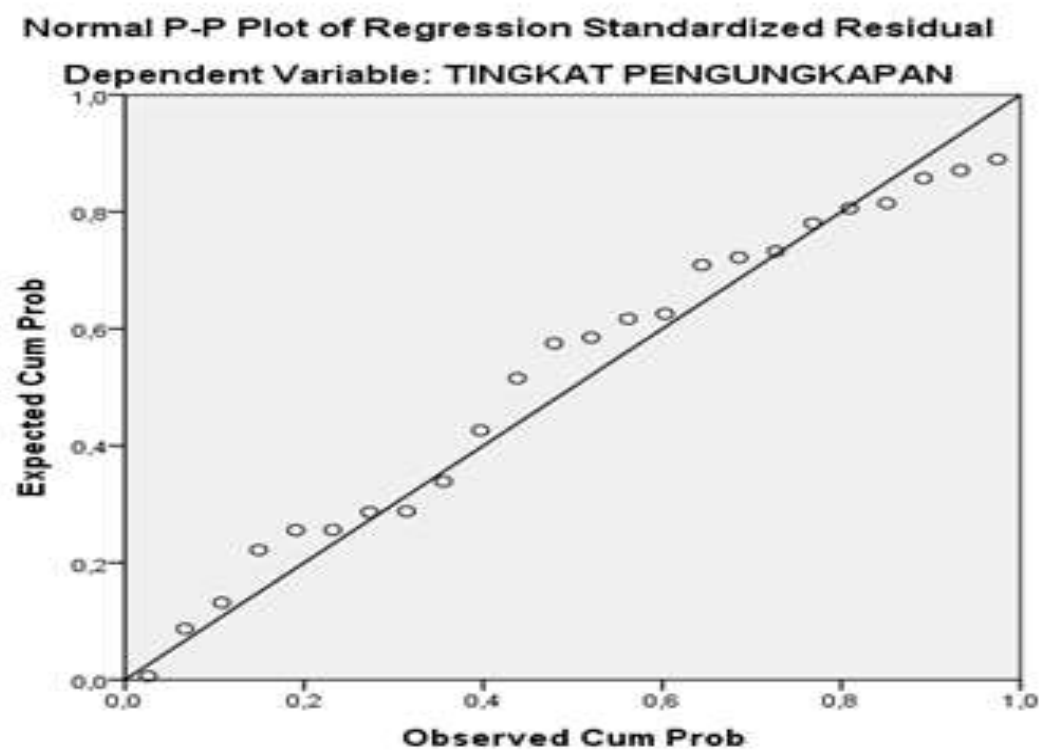

Berdasarkan gambar 4.2 menunjukan bahwa data terdistribusi normal karena titik menyebar di sekitar garis diagonal dan mengikuti arah garis diagonal, maka model regresi memenuhi asumsi normalitas.

Tabel 4.1

Hasil Uji One-Sample Kolmogrov-Smirnov

One-Sample Kolmogorov-Smirnov Test

\begin{tabular}{|ll|r|}
\hline & & $\begin{array}{r}\text { Unstandardized } \\
\text { Residual }\end{array}$ \\
\hline $\mathrm{N}$ & Mean & 24 \\
Normal & Std. Deviation & $0 \mathrm{E}-7$ \\
Parameters &, 03672813 \\
Most Extreme & Absolute &, 125 \\
Differences & Positive &, 089 \\
& Negative &,- 125 \\
Kolmogorov-Smirnov Z &, 610 \\
Asymp. Sig. (2-tailed) &, 851 \\
\hline
\end{tabular}

a. Test distribution is Normal.

b. Calculated from data.

Sumber: Output SPSS 20, data diolah(2017)

Berdasarkan tabel 4.1 hasil output menunjukan nilai One - Sample kolmogrov-Smirnov jika Sig. (p) >0,05 maka Ho diterima dan Jika Sig.(p) $<0,05$ maka Ha ditolak. Pada penelitian ini signifikan (p) adalah 0,851>0,05 berarti data berdistribusi normal.

Uji Multikolinearitas

Berdasarkan tabel 4.2 variance inflation factor (VIF) dan tolerance maka apabila 
VIF melebihi angkah 10 atau tolerance kurang dari 0,10 maka dinyatakan terjadi gejala multikokolineritas. Sebaliknya apabila nilai VIF kurang dari 10 atau tolerance lebih dari 0,10 maka dinyatakan tidak terjadi gejala multikolinearitas.

a. Nilai VIF untuk variabel laba sebesar $3,046<10$ dan nilai tolerance sebesar $0,328>0,10$ sehingga laba dinyatakan tidak terjadi multikolinieritas.

b. Nilai VIF untuk variabel leverage sebesar $1,408<10$ dan nilai tolerance sebesar $0,710>0,10$ sehingga leverage dinyatakan tidak terjadi multikolinieritas.

c. Nilai VIF untuk variabel ukuran perusahaan sebesar 3,444 $<10$ dan nilai tolerance sebesar $0,290>0,10$ sehingga ukuran perusahaan dinyatakan tidak terjadi multikolinieritas.

d. Nilai VIF untuk variabel likuiditas sebesar $1,212<10$ dan nilai tolerance sebesar $0,825>0,10$ sehingga likuiditas dinyatakan tidak terjadi multikolinieritas.

Tabel 4.2

\section{Hasil Uji Multikolinearitas}

\begin{tabular}{|l|r|c|}
\hline \multicolumn{3}{|c|}{ Coefficients $^{\mathbf{a}}$} \\
\hline \multirow{2}{*}{ Model } & \multicolumn{2}{|c|}{ Collinearity Statistics } \\
\cline { 2 - 3 } & Tolerance & \multicolumn{1}{c|}{ VIF } \\
\hline 1. (Constant) & & \\
LABA &, 328 & 3,046 \\
LEVERAGE &, 710 & 1,408 \\
UKURAN PERUSAHAAN &, 290 & 3,444 \\
LIKUIDITAS &, 825 & 1,212 \\
\hline
\end{tabular}

a. Dependent Variable: TINGKAT PENGUNGKAPAN

\section{Sumber :Output SPSS 20, data diolah(2017)}

Uji Heteroskedastisitas

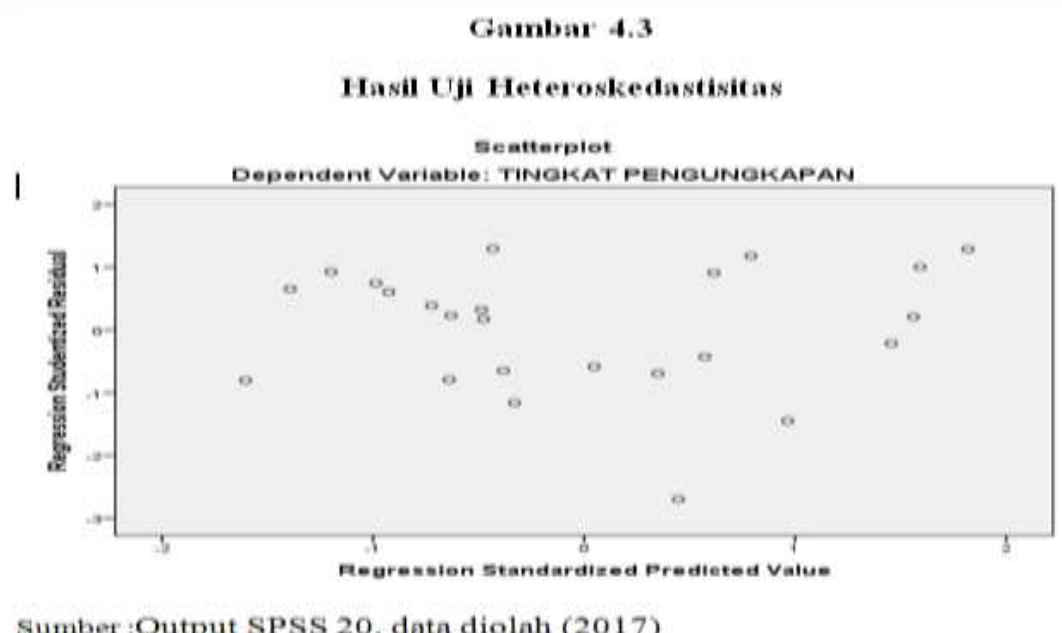

Sumber: Output SPSS 20, data diolah (2017) 
Berdasarkan Gambar 4.3 dari output diatas dapat diketahui bahwa titik-titik tidak membentuk pola yang jelas. Titiktitik menyeber diatas dan dibawah 0 pada

Uji Autokorelasi sumbu Y. jadi dapat disimpulkan bahwa pada uji heteroskdastisitas ini tidak mengalami masalah heteroskedastisitas dalam model regresi.

Tabel 4.3

Hasil Uji Autokorelasi

\begin{tabular}{|l|r|r|r|r|r|}
\hline Model & $R$ & R Square & $\begin{array}{c}\text { Adjusted R } \\
\text { Square }\end{array}$ & $\begin{array}{c}\text { Std. Error of the } \\
\text { Estimate }\end{array}$ & Durbin-Watson \\
\hline 1 & $782^{*}$ & 612 & 530 & .04041 & 1.610 \\
\hline
\end{tabular}

a. Predictors: (Constant), LABA, LEVERAGE, UKURAN PERUSAHAAMLIKUIDITAS

b. Dependent Variabie: TINGKAT PENGUNGKAPAN

Sumber: Output SPSS 20, data diolah (2017)

Berdasarkan tabel 4.3 dapat dilihat bahwa nilai Durbin-Wastson untuk penelitian ini adalah sebesar 1,610 maka penelitian ini dapat disimpulkan bahwa penelitian ini tidak tejadi autokorelasi. $\mathrm{d}_{\mathrm{U}}<\mathrm{d}<4-\mathrm{d}_{\mathrm{U}}$; maka tidak terjadi autokorelasi. Alasannya $1.7753>1,610$ $<4-1.9018$.

\section{Analisis Regresi Linier Berganda}

Tabel 4.4

Analisis Regresi Linier Berganda

Coefficients ${ }^{a}$

\begin{tabular}{|c|c|c|c|c|c|}
\hline \multirow[t]{2}{*}{ Model } & \multicolumn{2}{|c|}{$\begin{array}{c}\text { Unstandardized } \\
\text { Coefficients }\end{array}$} & \multirow{2}{*}{$\begin{array}{c}\text { Standardized } \\
\text { Coefficients } \\
\text { Beta }\end{array}$} & \multirow[t]{2}{*}{$\mathrm{t}$} & \multirow[t]{2}{*}{ Sig. } \\
\hline & $\mathrm{B}$ & Std. Error & & & \\
\hline (Constant) & 3,825 &, 066 & & 58,083 &, 000 \\
\hline LABA &,- 743 & ,207 &,- 894 & 3,581 &, 002 \\
\hline LEVERAGE &, 160 & ,068 &, 397 & 2,343 &, 030 \\
\hline $\begin{array}{l}\text { UKURAN } \\
\text { PERUSAHAAN }\end{array}$ &, 024 &, 005 & 1,379 & 5,199 &, 000 \\
\hline LIKUIDITAS & 008 & 013 & 096 & 613 & 547 \\
\hline
\end{tabular}

a. Dependent Variable: TINGKAT PENGUNGKAPAN

Sumber: Output SPSS 20, 2017 (data diolah) 
Berdasarkan tabel 4.3 diatas terlihat bahwa nilai konstanta a sebesar 3,825 dan koefesien regresi b1 -0,743,b2 0,160, b3 0,024, b4 0,008 . Nilai konstanta dan koefesien regresi (a, b1, b2, b3, b4) ini dimasukan dalam persamaan regresi linier berganda berikut ini :

$\mathrm{Y}=\mathrm{a}+\mathrm{b} 1 \mathrm{X} 1+\mathrm{b} 2 \mathrm{X} 2+\mathrm{b} 3 \mathrm{X} 3+\mathrm{b} 4 \mathrm{X} 4+\mathrm{e}$

Sehingga persamaan regresinya menjadi sebagai berikut :

$\mathrm{Y}=3,825-0,743 \mathrm{X} 1+0,160 \mathrm{X} 2+0,024$ $\mathrm{X} 3+0,008 \mathrm{X} 4+\mathrm{e}$

Nilai Konstanta sebesar 3,825 Hal ini menunjukan bahwa apabila variabel independen laba (X1), leverage (X2), ukuran perusahaan (X3), dan likuiditas (X4), tidak mengalami perubahan atau nilainya nol, maka nilai dari variabel dependen tingkat pengungkapan laporan keuangan (Y) adalah sebesar 3,825.

Laba $(X 1)=-0,743$ Merupakan nilai koefisien regresi variabel kinerja masa kini (X1) terhadap variabel tingkat pengungkapan laporan keuangan (Y) artinya jika kinerja masa kini (X1) engalami penurunan satu satuan maka tingkat pengungkapan laporan keuangan (Y) akan mengalami penurunan sebesar - 0,743 atau $7,43 \%$ koefisien bernilai negatif antara kinerja masa kini (X1) dan tingkat pengungkapan laporan keuangan (Y) hubungan negatif. Penurunan kinerja masa kini (X1) akan menyebabkan penurunan pada tingkat pengungkapan laporan keuangan (Y).

Leverage $(X 2)=0,160$ Merupakan nilai koefisien regresi variabel leverage (X2) terhadap variabel tingkat pengungkapan laporan keuangan $(\mathrm{Y})$ artinya jika leverage (X2) mengalami peningkatan satu satuan maka tingkat pengungkapan laporan keuangan akan mengalami peningkatan sebesar 0,160 atau
1,60\% koefisien bernilai positif artinya antara leverage (X2) dan tingkat pengungkapan laporan keuangan (Y) berhubungan positif. Kenaikan leverage (X2) akan mengakibatkan kenaikan pada tingkat pengungkapan laporan keuangan (Y).

Ukuran Perusahaan (X3) $=0,024$ Merupakan nilai koefisien regresi variabel ukuran perusahaan (X3) terhadap variabel tingkat pengungkapan laporan keuangan (Y) artinya jika ukuran perusahaan (X3) mengalami peningkatan satu satuan maka tingkat pengungkapan laporan keuangan akan mengalami peningkatan sebesar 0,024 atau 24\% koefisien bernilai positif artinya antara ukuran perusahaan (X3) dan tingkat pengungkapan laporan keuangan (Y) berhubungan positif. Kenaikan ukuran perusahaan (X3) akan mengakibatkan kenaikan pada tingkat pengungkapan laporan keuangan (Y).

Likuiditas $(\mathrm{X} 4)=0,008$ Merupakan nilai koefisien regresi variabel likuiditas (X4) terhadap variabel tingkat pengungkapan laporan keuangan (Y) artinya jika likuiditas (X4) mengalami peningkatan satu satuan maka tingkat pengungkapan laporan keuangan akan mengalami peningkatan sebesar 0,008 atau $0,08 \%$ koefisien bernilai positif artinya antara likuiditas (X4) dan tingkat pengungkapan laporan keuangan $(\mathrm{Y})$ berhubungan positif. Kenaikan likuiditas (X4) akan mengakibatkan kenaikan pada tingkat pengungkapan laporan keuangan (Y).

\section{Pengujian Hipotesis}

Uji Koefisien Determinasi $\left(\mathrm{R}^{2}\right)$ 
Tabel 4.4

Hasil Koefesien Determinasi $\left(\mathbf{R}^{2}\right)$

\begin{tabular}{|c|c|r|r|c|}
\hline \multicolumn{1}{|c|}{ Model Summary } \\
\hline 1 & $\mathrm{R}$ & $\mathrm{R}$ Square & $\begin{array}{c}\text { Adjusted } \mathrm{R} \\
\text { Square }\end{array}$ & $\begin{array}{c}\text { Std. Error of the } \\
\text { Estimate }\end{array}$ \\
\hline
\end{tabular}

a. Predictors: (Constant), LIKUIDITAS, LABA, LEVERAGE, UKURAN PERUSAHAAN

b. Dependent Variable: TINGKAT PENGUNGKAPAN

Sumber: Output SPSS 20, 2017 (data diolah)

Berdasarkan tabel 4.4 output SPSS terlihat bahwa dari hasil perhitungan diperoleh nilai (R Square) sebesar 0,612 (nilai 0,612 adalah pengkuadratan dari koefisien atau $\mathrm{R}$, yaitu $0,782 \times 0,782=$ 0,612. Besarnya angka koefisien determinasi ( $\mathrm{R}$ Square) 0,612 sama dengan 61,2\%. Angka tersebut mengandung arti bahwa kinerja masa kini, leverage, ukuran perusahaan, likuiditas berpengaruh terhadap tingkat pengungkapan laporan keuangan sebesar $61,2 \%$. Sedangkan sisanya $(100 \%$ $61.2 \%=38,8 \%$ ) dipengaruhi oleh variabel lain diluar model regresi ini. Besarnya pengaruh variabel kain ini sering di sebut sebagai error (e).

\section{Uji F (Secara Simultan)}

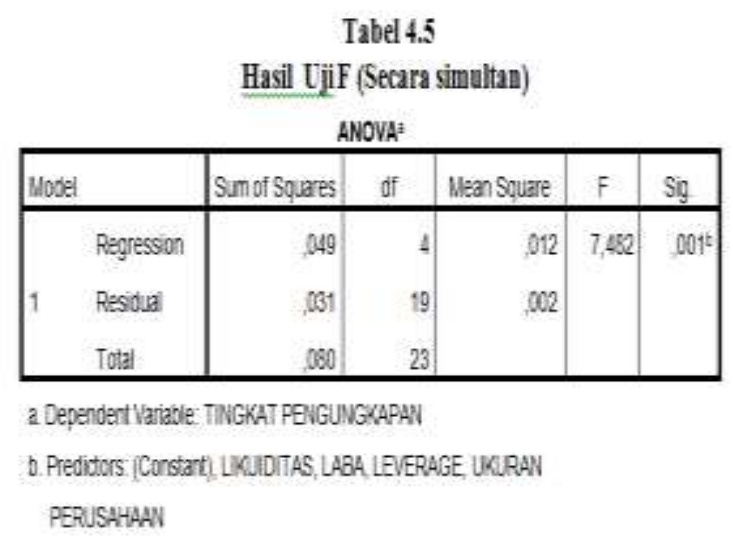

\section{Sumber: OutputSPSS20,2017(datadiolah)}

Dari tabel 4.5 hasil uji $\mathrm{F}$ secara simultan variabel independent menunjukan nilai $\mathrm{F}$ hitung 7,482 > F tabel 2,87 dan nilai signifikan $F \quad 0,001<\alpha 0,050$. sesuai dengan dasar pengambilan keputusan dalan uji $\mathrm{F}$ maka dapat di simpulkan bahwa, Hal ini menunjukan bahwa model penelitian variabel independen yaitu :

1. Variabel independent laba (X1) secara simultan berpengaruh terhadap variabel dependen tingkat pengungkapan laporan keuangan.

2. Variabel independent leverage (X2) secara simultan berpengaruh terhadap variabel dependen tingkat pengungkapan laporan keuangan

3. Variabel independent ukuran perusahaan (X3) secara simultan berpengaruh terhadap variabel dependen tingkat pengungkapan laporan keuangan.

4. Variabel independent likuiditas (X4) secara simultan berpengaruh terhadap variabel dependen tingkat pengungkapan laporan keuangan.

Uji T (Secara Parsial)

Dari tabel 4.7 ini hasil uji T secara parsial variabel independent menunjukan nilai Jika signifikansi < 0,050 maka Ho diterima dan Jika signifikansi > 0,050 maka Ho di tolak. Hipotesis yang dapat di simpulkan dalam penelitian ini adalah sebagai berikut :

1. Variabel independent laba (X1) dengan nilai T hitung 3,581 >1,730 sedangkan nilai signifikan dari hipotesis sebesar 0,002 < 0,050. Maka Ho diterima dan Ha1 diterima, dapat disimpulkan bahwa variabel kinerja masa kini (X1) berpengaruh signifikan terhadap tingkat pengungkapan laporan keuangan. 
Jurnal Manajemen dan Bisnis Vol. 11 No. 1 Oktober 2020: 7 - 18

2. Variabel independent leverage (X2) dengan nilai $\mathrm{T}$ hitung $2,343>1,730$ sedangkan nilai signifikan dari hipotesis sebesar $0,030<0,050$. Maka Ho diterima dan $\mathrm{Ha} 2$ diterima, dapat disimpulkan bahwa variabel leverage (X2) berpengaruh signifikan terhadap tingkat pengungkapan laporan keuangan.

3. Variabel independent ukuran perusahaan (X3) dengan nilai T hitung 5,199>1,730 sedangkan nilai signifikan dari hipotesis sebesar $0,000<0,050$. Maka Ho diterima dan $\mathrm{Ha} 3$ diterima, dapat disimpulkan bahwa variabel ukuran perusahaan (X3) berpengaruh signifikan terhadap tingkat pengungkapan laporan keuangan.

4. Variabel independent likuiditas (X4) dengan nilai $\mathrm{T}$ hitung $0,613<1,730$ sedangkan nilai signifikan dari hipotesis sebesar 0,547>0,050. Maka Ho di terima dan Ha4 ditolak, dapat disimpulkan bahwa variabel likuiditas (X4) tidak berpengaruh signifikan terhadap tingkat pengungkapan laporan keuangan.

Tabel4.6

Hasil Uji T (Secara Parsial)

Coefficients $^{\mathrm{a}}$

\begin{tabular}{|c|c|c|c|c|c|}
\hline \multirow[t]{2}{*}{ Model } & \multicolumn{2}{|c|}{$\begin{array}{c}\text { Unstandardized } \\
\text { Coefficients }\end{array}$} & \multirow{2}{*}{$\begin{array}{c}\text { Standardized } \\
\text { Coefficients } \\
\text { Beta }\end{array}$} & \multirow[t]{2}{*}{$\mathrm{t}$} & \multirow[t]{2}{*}{ Sig. } \\
\hline & B & Std. Error & & & \\
\hline (Constant) & 3,825 &, 066 & & 58,083 &, 000 \\
\hline LABA &,- 743 & 207 &,- 894 & $-3,581$ &, 002 \\
\hline LEVERAGE & , 160 &, 068 &, 397 & 2,343 &, 030 \\
\hline UKURAN & & & & & \\
\hline PERUSAHAAN & , 024 & 年, & $1,3 / 9$ & 5,199 & , \\
\hline LIKUIDITAS &, 008 &, 013 &, 096 &, 613 &, 547 \\
\hline
\end{tabular}

a. Dependent Variable: TINGKAT PENGUNGKAPAN

Sumber: Output SPSS 20, data diolah(2017)

Dari tabel 4.7 ini hasil uji T secara parsial variabel independent menunjukan nilai Jika signifikansi $<0,050$ maka Ho diterima dan Jika signifikansi > 0,050 maka Ho di tolak. Hipotesis yang dapat di simpulkan dalam penelitian ini adalah sebagai berikut :

1. Variabel independent laba (X1) dengan nilai Thitung 3,581>1,730 sedangkan nilai signifikan dari hipotesis sebesar 0,002 < 0,050. Maka Ho diterima dan Ha1 diterima, dapat disimpulkan bahwa variabel kinerja masa kini (X1) berpengaruh signifikan terhadap tingkat pengungkapan laporan keuangan.

2. Variabel independent leverage (X2) dengan nilai $\mathrm{T}$ hitung 2,343>1,730 sedangkan nilai signifikan dari hipotesis sebesar 0,030 < 0,050. Maka Ho diterima dan $\mathrm{Ha} 2$ diterima, dapat disimpulkan bahwa variabel leverage (X2) berpengaruh signifikan terhadap tingkat pengungkapan laporan keuangan.

3. Variabel independent ukuran perusahaan (X3) dengan nilai $\mathrm{T}$ hitung 5,199 > 1,730 sedangkan nilai signifikan dari hipotesis sebesar $0,000<0,050$. Maka Ho diterima dan $\mathrm{Ha} 3$ diterima, dapat disimpulkan bahwa variabel ukuran perusahaan (X3) berpengaruh signifikan terhadap tingkat pengungkapan laporan keuangan.

4. Variabel independent likuiditas (X4) dengan nilai $\mathrm{T}$ hitung $0,613<1,730$ sedangkan nilai signifikan dari hipotesis sebesar 0,547>0,050. Maka Ho di terima dan $\mathrm{Ha} 4$ ditolak, dapat disimpulkan bahwa 
variabel likuiditas (X4) tidak berpengaruh signifikan terhadap tingkat pengungkapan laporan keuangan.

\section{KESIMPULAN DAN SARAN}

Berdasarkan hasil analisis data dan uraian uraian yang telah dipaparkan dapat di tarik kesimpulan sebagai berikut :

1. Berdasarkan hasil pengujian dengan menggunakan regresi linier berganda, dapat disimpulkan bahwa variabel laba (X1) berpengaruh signifikan terhadap tingkat pengungkapan laporan keuangan dengan nilai signifikan $\mathrm{T}$ $(0,002)<\alpha(0,050)$ dan di lihat dari nilai T Hitung 3,851>1,730.

2. Berdasarkan hasil pengujian dengan menggunakan regresi linier berganda, dapat disimpulkan bahwa variabel leverage (X2) berpengaruh signifikan terhadap tingkat pengungkapan laporan keuangan dengan nilai signifikan $\mathrm{T}(0,030)>\alpha(0,050)$. dan di lihat dari nilai $\mathrm{T}$ hitung 2,343 > 1,730 .

3. Berdasarkan hasil pengujian dengan menggunakan regresi linier berganda, dapat disimpulkan bahwa variabel ukuran perusahaan (X3) berpengaruh signifikan terhadap tingkat pengungkapan laporan keuangan dengan nilai signifikan $\mathrm{T}$ $(0,000)<\alpha(0,050)$. dan di lihat dari nilai Thitung 5,199>1,730.

4. Berdasarkan hasil pengujian dengan menggunakan regresi linier berganda, dapat disimpulkan bahwa variabel likuiditas (X4) tidak berpengaruh signifikan terhadap tingkat pengungkapan laporan keuangan dengan nilai signifikan $\mathrm{T}(0,547)>\alpha$ $(0,050)$. Dan di lihat dan nilai Ttabel, nilai $\mathrm{T}$ hitung $0,613<1,730$ dapat disimpulkan bahwa variabel likuiditas (X4) tidak berpengaruh signifikan terhadap tingkat pengungkapan laporan keuangan.

5. Hasil Uji Hipotesis dengan menggunakan uji $\mathrm{F}$ (secara simultan) menunjukan nilai F hitung 7,48 > 2,87 dan signifikan $\mathrm{F}(0,001)<\alpha(0,050)$ maka dapat disimpulkan laba (X1), leverage (X2), Ukuran perusahaan (X3) dan likuiditas (X4) secara bersama-sama berpengaruh secara signifikan terhadap tingkat pengungkapan laporan keuangan.

Setelah melakukan penelitian, pembahasan, dan merumuskan kesimpulan dari hasil penelitian, maka penulis memberikan beberapa saran yang berkaitan dengan penelitian yang telah dilakukan untuk dijadikan masukan dan bahan pertimbangan yang berguna bagi pihak-pihak yang berkepentingan, antara lain sebagai berikut:

1. PT Charoen Pokphand Indonesia Tbk hendaknya mempertahankan Manajemen Laba dalam perusahaan. Supaya laba yang di hasilkan oleh perusahaan bisa meningkat setiap tahunnya.

2. Dalam penelitian ini, selanjutnya yang ingin melakukan penelitian sejenis, sebaiknya menggunakan sampel yang lebih besar dan waktu pengamatan yang lebih banyak sehingga hasil penelitian diharapkan lebih baik dan akurat.

3. Penelitian selanjutnya hendak menambahkan variabel lain seperti kinerja masa depan, asimetri informasi, return kumulatif, yang dapat mewakili karakteristik perusahaan yang berpengaruh terhadap tingkat pengungkapan laporan keuangan

\section{DAFTAR PUSTAKA}

Baridwan Zaki. 2012. Intermediate accounting. Yogyakarta : BPFE.

Belkaoui, Ahmed Riahi, 2006. Teori Akuntansi, Edisi Kelima. Jakarta : Salemba Empat.

Gunawan, Imam. 2014. Metode Penelitian Kualitatif : Teori dan Praktik. Jakarta: Bumi Aksara. 
Imhoff. 2003. Akuntansi Kualitas dan Tata Perusahaan Kelola Perusahaan. Jakarta : Salemba Empat.

Jusuf Soewadji. 2012. Pengantar metodelogi penelitian. Jakarta: Mitra Wacana Media.

Kasmir. 2012. Analisis laporan keuangan. Jakarta: Rajawali Pers.

Nazir,Muhammad.2011. Metode penelitian. Jakarta: Ghalia Indonesia perusahaan. Jakarta: PT. Gramedia Pustaka Utama.

Prastowo Dwi. 2008. Analisis laporan keuangan konsep dan aplikasinya.

Yogyakarta: Sekolah Tinggi Ilmu Manajemen YKPN.

Priyatno, Duwi. 2012. Cara Kilat Belajar Analisis Data dengan SPSS 20.

Yogyakarta: Andi Offset.

Sanusi, Anwar. 2011. Metode penelitian bisnis. Jakarta: Salemba Empat.

Slamet Sugiri. 2005. Akuntansi Manajemen. Yogyakarta: BPFE

Sri Sulistyanto, 2008, Manajemen Laba teori dan model empiris. Jakarta : Grasindo

Surat Edaran Badan Pengawas Pasar Modal (BAPEPAM) Lampiran Nomor KEP-431/BL/2012 Tentang Pedoman Penyajian dan Pengungkapan Laporan Keuangan Emiten atau Perusahaan Publik.

Suwardjono. 2008. Teori Akuntansi Perekayasaan Pelaporan Keuangan. Yogyakarta : BPFE

Wallace, L Walter. 1994. Metode Logika Ilmu Sosial, Edisi Keempat, Cetakan Kedua, Alih Bahasa Tim Yasogama. Jakarta : Bumi Aksara.

Jurnal :

Gumanti Tatang, Ary, Analisis Perataan Laba dan Faktor Faktor Yang Mempengaruhi : Studi Empiris Pada Perusahhan Di Indonesia. Di akses eprints.undip.ac.id/44019/1/18_Ag ustianto.pdf. Pada tanggal 04 April 2017.pukul 17.19 WIB.

Hadri, Kusuma. 2006. Dampak Manajemen Laba Terhadap Relevansi Informasi Akuntansi :
Bukti Empiris Dari Indonesia. Di akses di http://jurnalakuntansi.petra.ac.id/in dex.php/aku/article/view/16578. Pada tanggal 04 April 2017 pukul 16.05 WIB.

Pujiningsih. 2011. Pengaruh Struktur Kepemilikan, Ukuran Perusahaan, Praktik Corporate Governance Dan Kompensasi Bonus Terhadap Manajemen Laba. Di akses di eprints.undip.ac.id/28571/1/Skripsi 5.pdf. Pada tanggal 11 Juni 2017 pukul 21.30 WIB.

Purba Kristy, Riky. 2014, Analisis Pengaruh Manajemen Laba Terhadap Tingkat Pengungkapan Laporan Keuangan. Diakses di http://repository.stiesia.ac.id/395/.

Pada tanggal 12 Juni 2017 pukul 20 : 15 WIB.

Rahmawati. 2006 . Faktor-Faktor Manajemen Laba. Di akses http://eprints.undip.ac.id/37149/1/R ahmawati.pdf. Pada tanggal 05 April 2017. 17.26 WIB.

Tanor.2009. Pentingnya Pengungkapan Laporan Keuangan Tahunan. Di aksesrepository.stiesia.ac.id/111/8/ Daftar\%20Pustaka.pdf.Pada tanggal 06 April 2017 pukul 17.08 WIB.

www.idx.co.id

Yuliana Mieke, 2015. Faktor Faktor Yang Mempengaruhi Manajemen Laba Pada Perusahaan Sektor Perbankan Yang Terdaftar Di Bursa Efek Indonesi (BEI). Di akses di http://digilib.binadarma.ac.id/downloa d.php?id=1161. Pada tanggal 04 April 2017. Pukul 16.10 WIB. 